\title{
Acidentes de trabalho na Colômbia. Doutrina, lei e jurisprudência (1915-1950)
}

\author{
Óscar Gallo*
}

Resumo: o artigo problematiza a doutrina, a lei e a jurisprudência sobre os acidentes de trabalho na Colômbia, principalmente a Lei $n^{\circ} 57$, de 1915 . Baseado em teses de médicos e advogados propõe que houve outros vazios jurídicos, além da conhecida crítica à pobre abrangência da lei que vários historiadores têm mencionado. Igualmente, analisa a incorporação da doutrina do risco e o papel do discurso médico. Ademais, analisa as diferenças entre médicos gerais, médicos do trabalho e advogados no momento de avaliar a incapacidade ou consequência de um acidente do trabalho, entre os anos 1915 e 1945.

Palavras-chave: acidentes do trabalho; legislação trabalhista; medicina do trabalho.

Abstract: the article discusses the doctrine, the law and the jurisprudence on the industrial accidents in Colombia, mainly Law 57 of 1915. Based in thesis of doctors and lawyers, proposes that there were other legal voids, in addition to the known criticism of poor scope of law. Equally, it analyzes the incorporation of the doctrine of the risk and the role of the medical discourse. Moreover, analyzes differences between general and medical doctors of the work and lawyers to the moment to evaluate the incapacity or consequences of an employment-related accident.

Keywords: accidents at work; labor legislation; occupational medicine.

\section{Introdução}

Este artigo problematiza a doutrina, a lei e a jurisprudência sobre os acidentes de trabalho. Baseado principalmente em teses de advogados e médicos, se propõe que, além da conhecida crítica à pobre abrangência da lei destacada

* Historiador de la Universidad Nacional de Colombia - Sede Medellín (2004), mestre em História - Universidad Nacional de Colombia - Sede Medellín (2010) y doctor en historia de la Universidad Federal de Santa Catarina (2015). Actualmente es profesor de la Universidad Eafit e investigador de la Escuela Nacional Sindical de Colombia. 
por alguns historiadores ${ }^{1}$, houve outros vazios jurídicos. Para dizer de outra forma, trata-se de visualizar as fragilidades da Lei $n^{\circ} 57$, de 1915, na maneira como foram identificadas por advogados e médicos nos anos 1930 e 1940. De nenhuma forma se trata de observar com os elementos críticos do presente as fragilidades de uma lei do passado.

As críticas e os exemplos analisados neste artigo apontam o fracasso da lei. No entanto, são suficientes para afirmar categoricamente a ineficácia da primeira política social do país? No estado atual da pesquisa sobre esta questão na Colômbia, é empiricamente inviável inferir o pleno fracasso. Existem poucos registros sobre as atividades e os conflitos nesse campo desde a promulgação da lei em 1915. O pouco que se conhece foi publicado a partir de 1924, pelo Ministério da Indústria, e logo depois pelo jornal da Oficina Nacional del Trabajo. De fato, seria melhor dizer que podem existir muito mais informações, mas estão dispersas pelos tribunais da justiça comum. A mesma condição de dispersão pode-se imaginar para o caso dos arquivos empresariais.

A solução à escassez de fontes foi propor a análise crítica nos termos com que se manifestaram os médicos e advogados contemporâneos. Para muitos deles, havia na lei vários problemas que limitavam sua aplicação. Outra possibilidade teria sido abordar os casos de acidentes de trabalho, analisar os debates periciais e as resoluções do escritório encarregado, tanto qualitativa quanto quantitativamente. Além de ser um trabalho dispendioso, não é o caminho para apreender o nível de aplicação ou resistência do patronato colombiano, pois, obviamente, tal atitude não foi expressa nos jornais institucionais. ${ }^{2}$

A historiografia colombiana não tem problematizado as dimensões jurídica, médica, política e social dos acidentes de trabalho. Alguns estudos de caso avançam no conhecimento das formas de assistência médico-social para os trabalhadores em diferentes setores industriais, bem como na maneira com a qual os médicos lidaram com doenças e acidentes de trabalho. ${ }^{3} \mathrm{Em}$ uma perspectiva mais ampla, a historiografia colombiana sobre a saúde coletiva e a seguridade social coincide com a história social e política em dois aspectos. Primeiro, as leis trabalhistas eram um mecanismo da classe política para prevenir "o sentimento socialista" e o descontentamento da classe trabalhadora. Segundo, a Lei $n^{\circ}$ 57, de 1915, e as reformas posteriores, favoreceram um reduzido grupo de trabalhadores, agudizando o caráter paternalista e o modelo de assistência sem Estado. ${ }^{4}$

Em conclusão, está tudo por fazer em relação aos acidentes de trabalho na Colômbia. No entanto, considerando a riqueza dessa temática, é preciso

1 Veja-se por exemplo: HERNÁNDEZ, Mario. La salud fragmentada. Bogotá: Universidad Nacional, 2002, p. 81.

2 Finalmente, as atas de visitas praticadas pelo inspetor de fábricas de Medellín, oferecem um panorama regional de 1919-1927 acerca da acidentalidade na indústria de Antioquia. Se se aceita o dito pelo inspetor, as empresas cumpriam plenamente a legislação, no entanto, se percebe um problema neste tipo de fonte. A forma como se expressava esse tipo de acontecimentos disse muito pouco acerca da indenização. No onze de julho de 1920, Luis Escobar, operário da Fábrica Tejidos Rosellón perdeu duas terceiras partes do dedo anular da mão direita "ao verificar um trabalho na máquina lubrificadora". De acordo com o inspetor de fábricas, Daniel Vélez, o administrador deu conta do acidente ao juiz municipal e ao Dr. Eduardo Uribe, cumprindo o Artigo 12 da Lei n 57 de 1915 "afim de prestar ao incapacitado a assistência médica imediata". Archivo Histórico de Antioquia. Fondo Inspección de Fábricas. Tomo 8930. Acta 133 del 5 de julio de 1920.

3 RESTREPO, Libia. La práctica médica en el Ferrocarril de Antioquia. Medellín: La carreta, 2004; GALLO, Óscar. "Modelos sanitarios, prácticas médicas y movimiento sindical en la minería antioqueña. El caso de la Empresa Minera El Zancudo 1865-1950". (Dissertação, mestrado em Historia, Universidad Nacional de Colombia. Medellín, 2010); LUNA-GARCÍA, Jairo Ernesto. "Configuración de la salud obrera en la Tropical Oil Company: Barrancabermeja 1916-1951”. (Tese de Historia, Universidad Nacional de Colombia, Bogotá, 2011).

4 HERNÁNDEZ. La salud fragmentada, p. 81. 
fazer algumas escolhas ou três advertências. Em primeiro lugar, não interessa neste artigo discutir a quantidade de acidentes de trabalho que aconteceram na Colômbia entre 1915 e 1946. Está claro, para mim, que qualquer cifra aproximada pode ser aterradora. Em essência, o que interessa analisar são os debates jurídicos e médicos sobre a lei de acidentes de trabalho. E por que priorizar esta questão? Ao menos para o caso colombiano, na primeira metade do século XX, advogados e médicos estão mais interessados em criar os instrumentos para avaliar o problema e não tanto para medi-lo. Ou seja, nessas décadas, a medicina do trabalho passou por uma fase fundamentalmente teórica. ${ }^{5} \mathrm{~A}$ segunda advertência, diz respeito ao recorte temporal e a utilização das fontes. A primeira data evidentemente corresponde à Lei 57. A segunda, à formulação da Lei $n^{\circ} 6$, de 1945. No que diz respeito aos acidentes de trabalho, a definição incorporada em 1945 permaneceu praticamente invariável até o século XXI, dado que foi incluída no "Código Substantivo do Trabalho", aspecto impossível de analisar no espaço deste artigo. O leitor do artigo pode sentir falta de uma cronologia mais apurada dos processos históricos. Inclusive pode sentir certa confusão temporal. Porém, deve-se dizer que os saltos visíveis ou temporalidade das fontes se explica porque o artigo foca na análise hermenêutica da lei ou na maneira como os advogados da época interpretaram tanto o espírito como a abrangência da Lei $n^{\circ} 57$ de 1915. Deste ponto, pode-se extrair uma última advertência: o leitor colombiano e estrangeiro pode sentir a necessidade de uma exploração biográfica dos autores mencionados no texto, porém, se considera ao menos nesse artigo, irrelevante para a análise do problema principal.

Mas antes de analisar concretamente a legislação e a jurisprudência colombiana sobre acidentes do trabalho, cabe fazer uma reflexão sobre o horizonte da discussão na América Latina. Nas décadas de 1910 e 1920, os países do continente, sem exceção, criaram legislações sobre acidentes de trabalho, da mesma forma que o fizeram Alemanha (1884), Áustria (1887), Noruega (1894), Itália (1898), França (1898), Espanha (1900), Holanda e Suécia (1901), Luxemburgo (1902), Bélgica (1903), Inglaterra (1906), Hungria (1907), Sérvia (1910), Suíça (1911), Romênia (1912) e Dinamarca (1920). Assim, foram criadas legislações trabalhistas na Guatemala (1906), em El Salvador (1911), Peru (1911), Argentina (1915), Colômbia (1915), Venezuela (1915), Cuba (1916), Chile (1916), Panamá (1916), México (1917), Brasil (1919), Uruguai (1920), Equador (1921), Bolívia (1924), Costa Rica (1925). ${ }^{6}$ Nos Estados Unidos igualmente, como em New York (1898), Maryland (1902), Massachusetts (1908) e Montana (1909). ${ }^{7}$

Não obstante, a questão era menos homogênea e o amparo ao trabalhador podia mudar de um lugar para outro. Por exemplo, na Argentina, os horários de trabalho, os salários e o alcance das leis trabalhistas mudavam de acordo com o

5 Para esta afirmação nos baseamos fundamentalmente nos trabalhos de pesquisa recentes. $O$ autor mostra que nos anos 1930 e 1940 a medicina do trabalho na Colômbia passou por uma fase teórica antes que empírica. Ou seja, antes de observar os trabalhadores na fábrica, os médicos do período enfatizaram na legitimação de seu campo de saber. Mais detalhes sobre esta discussão, veja-se: GALLO, Óscar. "Higiene industrial y medicina del trabajo en Colombia, 1912-1948". In: CARDONA RODAS, Hilderman; PEDRAZA GÓMEZ, Zandra (Eds.). Al otro lado del cuerpo. Estudios biopolíticos en América Latina. Bogotá: Universidad de los Andes, 2014, p. 239-272; GALLO, Óscar. "Trabalho, medicina e legislação na Colômbia, 1910-1914". (Tese Doutoral, Universidade Federal de Santa Catarina, Florianópolis, 2015).

6 Veja-se: POBLETE TRONCOSO, Moisés. “Labour legislation in Latin America: I". International labour review, v. 17, n. 1, p. 51-68, 1928; POBLETE TRONCOSO, Moisés. "Labour legislation in Latin America: I-II”. International Labour Review, v. 17, n. 2, p. 204-230, 1928; REPÚBLICA DE COLOMBIA. MINISTERIO DE INDUSTRIAS. Memoria presentada al Congreso de 1927. Bogotá: Imprenta Nacional, 1927, p. 63.

7 GUYTON, Gregory P. “A Brief History of Workers' Compensation”. The lowa Orthopaedic Journal, v. 19, p. 106-110, 1999. 
sistema federal ou provincial que regia o trabalhador. ${ }^{8} \mathrm{~A}$ disparidade podia ser de tal magnitude que doze estados mexicanos possuíam leis trabalhistas, enquanto, na véspera da promulgação da Lei Federal do Trabalho, em 1931, quatro estados e o Distrito Federal careciam de regulamentação sobre acidentes de trabalho. ${ }^{9} \mathrm{Em}$ caso de incapacidade permanente e total, o trabalhador acidentado podia receber uma pensão vitalícia equivalente à metade do salário, ao passo que em outro lugar da federação, o montante da pensão vitalícia seria a totalidade do salário durante os anos de vida provável, ou ainda, um pedaço de terra. ${ }^{10}$ Posteriormente, os contratos coletivos de trabalho, em detrimento dos individuais, introduziram outro fator na proteção social. Os sindicatos mais fortes, amiúde de ferrovias ou transportes, podiam alcançar melhores condições para os associados. A reclamação individual era sempre menos eficaz que a resolução coletiva.

Em princípio a proteção limitou-se aos acidentes de trabalho, e o problema das doenças ocupacionais foi adiado até as décadas de 1930 e 1940. Mas na prática, houve muita elasticidade na interpretação dos limites possíveis de aplicação da lei, de maneira que as doenças desconsideradas no registro dos acidentes de trabalho, eventualmente, eram indenizadas por algum tribunal de justiça.

Para a maioria dos historiadores, as razões pelas quais se deu esse tipo de intervenção social do Estado mudavam de um lugar para outro, porém, coincidiam num ponto: no final do século XIX, os reformadores sociais estavam conscientes dos efeitos colaterais do progresso industrial e dos benefícios econômicos da saúde. Com efeito, o reconhecimento dos perigos da sociedade industrial e do maquinismo não era novidade. Entre 1830 e 1860, foram realizadas várias investigações médicas, nas quais a pobreza foi a figura central. Nessas primeiras "epidemiologias urbanas", o fator profissional estava atrelado aos problemas da higiene pública. No entanto, a "violência, quotidiana ou acidental, física ou moral" do trabalho começava a revelar-se, ao mesmo tempo em que se perfilava um saber científico sobre os corpos em risco. ${ }^{11}$

O que se dizia com sofisticação científica já era parte do inventário de experiências traumáticas dos operários desde começos do século XIX. Em toda parte, pululavam relatos sobre ruídos enlouquecedores, fábricas com pouca luz, filhos perdidos em acidentes, crianças doentias e frágeis, organismos enfraquecidos pelo trabalho ou "máquinas come-homens". Entretanto, as estatísticas sobre a questão estão despojadas de qualquer credibilidade em quase todos os países do mundo. Quando existem, como afirma Georges Friedmann, "sempre se deve pensar que o número de acidentes é maior". ${ }^{12}$

Assim, os acidentes de trabalho constituíam um problema real do ponto de vista individual e coletivo. Além dos efeitos negativos da industrialização, alguns historiadores observam que, mais que reformas sociais efetivas, o que houve foram soluções compatíveis com os interesses industriais ou adaptações do paternalismo industrial aos desafios produtivos do século XX que se iniciava. A reparação ao trabalhador permanecia como expressão do paternalismo industrial. No mesmo horizonte, as leis trabalhistas seriam a consolidação de uma

8 RAMACCIOTTI, Karina Inés. "De la culpa al seguro. La ley de accidentes de trabajo, Argentina (1915-1955)". Revista Mundos do Trabalho, v. 3, n. 5, p. 266-284, 2011, p. 276.

9 RAJCHENBERG, Enrique. "De la desgracia al accidente de trabajo. Caridad e indemnización en el México revolucionario". Estudios de Historia Moderna y Contemporánea de México, v. 15, p. 85-113, 1992, p. 106.

10 RAJCHENBERG. "De la desgracia al accidente de trabajo".

11 MORICEAU, Caroline. «Les perceptions des risques au travail dans la seconde moitié du XIXe siècle: entre connaissance, déni et prévention». Revue d'Histoire Moderne et Contemporaine, v. 56, p. 11-27, 2009.

12 FRIEDMANN, Georges. Problemas humanos del maquinismo industrial. Buenos Aires: Suramericana, 1956, p. 135. 
tolerância estatal controlada, que permitia minorar o descontentamento social e abrandar a radicalidade dos nascentes movimentos operários. Em outras palavras, a lei sobre acidentes, como amostra dos dispositivos de persuasão e coerção da classe operária, era manifestação do interesse do governo em instaurar uma falsa harmonia de interesses, baseada numa desejada coesão social.

Outros pesquisadores veem nos movimentos operários e na pressão popular, real ou simbólica, as razões pelas quais, nessa primeira metade do século XX, e não antes, se legislou sobre as questões relativas ao mundo do trabalho. ${ }^{13}$ No entanto, como a intensidade do conflito entre capital e trabalho mudava de um lugar para outro, o impacto da formulação das leis era diferente. No México, na Argentina e no Brasil, por exemplo, ações populares de ordem local ou nacional puderam impulsionar a política nacional no campo dos direitos sociais, ao passo que na Colômbia, o papel do movimento operário parece ter sido mais tímido. Para outros autores ainda, os países da América Latina produziram uma imprevista imitação das leis sociais da Europa, principalmente das francesas e espanholas. O que explicaria, a tendência generalizada de se proteger unicamente os trabalhadores urbanos, e o marasmo frente às péssimas condições dos camponeses, mesmo tratando-se de sociedades predominantemente agrícolas? ${ }^{14}$

Pode-se pensar que todos têm razão. Houve, em vários países, uma participação ativa da burguesia industrial na formulação das políticas sociais, mas isto não teria acontecido sem a ressonância das reivindicações operárias. Mais que simples imitação, houve uma sorte de "paritarismo" reformador, suscitado pelas condições sociais e políticas da época e pela sutil inspiração de outros países, ou por pressão de organismos internacionais, como foram os casos da Organização Internacional do Trabalho e a Conferência Pan-Americana nos anos $1920 .{ }^{15}$ Finalmente, não se pode esquecer que, em países amplamente católicos como a Colômbia, houve ressonância dos pensadores cristãos do século XIX e, de modo geral, da doutrina social da igreja ou do cristianismo social de Leão XIII' ${ }^{16}$.

Em relação às consequências da lei sobre acidentes, está claro que a transição da culpa à noção do risco significou o rompimento definitivo com a ideia de fatalidade, infortúnio e o que teria de metafísico, imprevisível ou natural. Ponderar o risco de acidente significou estimar, comunicar e administrar cadeias causais que iam da pobreza até os fatores hereditários, fisiológicos e psicológicos, passando pelas doenças sociais. Como afirmou Enrique Rajchenberg, "muitas fatalidades juntas não são iguais à somatória de acasos individuais". ${ }^{17}$

Ao fazer de episódios individuais problemas coletivos, o acidente tornouse "conceito e princípio de objetivação". ${ }^{18}$ Como artifício conceitual, definiu um

13 RAMACCIOTTI. "De la culpa al seguro".

14 Existem na historiografia colombiana registros de ações muito específicas de atenção para alguns trabalhadores rurais e uma situação igual deve ter-se apresentado em outras regiões do continente. Como parte da implementação de modelos de atenção médico-social de certas indústrias e empresas, destaca-se o caso do Ferrocarril de Antioquia que prestava atenção em saúde aos trabalhadores agrícolas. RESTREPO. La práctica médica en el Ferrocarril de Antioquia. Também sabe-se que algumas fazendas cafeeiras como La Suiza de César Piedrahita e El Corcovado de Francisco Navech em Antioquia (Colômbia), dispunham de médicos e campanhas contra a ancilostomíase. CALLE, Miguel María. "Apuntes para el estudio de la anquilostomiasis". Anales de la Academia de Medicina de Medellín, v. XV, n. 3, p. 67-89, 1910, p. 83. Em qualquer caso, estas eram exceções pois o mais comum foi a negação de médico ou formas de proteção social para os camponeses.

15 Sobre paritarismo, ver: BUZZI, Stéphane; DEVINCK, Jean-Claude; ROSENTAL, Paul-André. La santé au travail, 1880-2006. Paris: La Découverte, 2006, p. 29.

16 AVELLA GÓMEZ, Mauricio. Las instituciones laborales en Colombia. Contexto histórico de sus antecedentes y principales desarrollos hasta 1990. Bogotá: Universidad de Bogotá Jorge Tadeo Lozano, 2012.

17 RAJCHENBERG. "De la desgracia al accidente de trabajo".

18 EWALD, François. L’Etat Providence. Paris: Bernard Grasset, 1986, p. 336. 
conjunto de acontecimentos prováveis vinculados ao mundo laboral. Uma série de fatos que, ainda que "imprevistos e repentinos", eram passíveis de serem estudados cientificamente. A prevenção do acidente se inseria, então, a meio caminho entre o conhecimento das probabilidades estatísticas e a intervenção médica no âmbito das liberdades individuais.

A lógica do risco profissional capitalizou paulatinamente o corpo do trabalhador, e por essa via, se produziu a legitimação e a acomodação da figura do especialista em medicina legal; enquanto principal avaliador do risco, da capacidade e da incapacidade do indivíduo, o especialista do trabalho concentrou sua atividade na perícia, na assistência médica e, em menor medida, na reabilitação dos trabalhadores acidentados. ${ }^{19}$

George Duhamel afirma que a lei sobre os acidentes de trabalho colaborou para que a "indústria bastarda" das companhias de seguros rompesse o "colóquio" entre doente e médico. Assim, com a aparição desse "terceiro que paga" no cenário social e médico, os métodos aritméticos começaram a ser aplicados a fenômenos incomensuráveis. Ao sofrimento do doente e às fadigas do médico foi imposta a tarifa de um sistema forçosa e puramente extensivo. ${ }^{20}$

Cabe anotar que as críticas de Duhamel ao "terceiro que paga" não questionavam o sistema no que tinha de injusto ou perverso para o trabalhador. Fazia a defesa do grêmio médico perante o que considerava a burocratização e a estatização da prática médica, ou seja, defendia a independência dos médicos nos campos profissional e econômico. Em todo caso, a crítica ao processo de acomodação e cooptação dos médicos é muito interessante, pois no fundo, as questões eram: como se pode configurar uma espécie de deontologia do trabalho médico-legal em casos de acidentes de trabalho, quando as exigências e intervenções desse terceiro que paga são determinantes? O quanto os modelos matemáticos e os artifícios procedimentais acomodam a resposta médica a banais interesses econômicos?

Díspar e limitada em muitos países, por beneplácito da burguesia ou por pressão dos movimentos operários, o fato é que a lei sobre acidentes de trabalho teve profundas consequências políticas. Não só inaugurou a ruptura do direito trabalhista com o "velho tirano, o direito civil", ${ }^{21}$ mas também, na maioria dos casos, antecipou outras leis que determinaram obrigações sociais e responsabilidades jurídicas ao conjunto social. Em resumo, ao desnaturalizar o infortúnio, a lei possibilitou que os trabalhadores reivindicassem dos patrões assistência médica e compensação econômica em razão do risco e da injustiça. Em consequência, esperava-se que crescesse a preocupação pelas condições de higiene e os perigos do trabalho.

Os historiadores têm-se debruçado sobre a aplicação efetiva da lei, observando os inúmeros mecanismos patronais para isenção da culpa ou atenuação de responsabilidades. Neste ponto, é ainda mais delicado estabelecer um consenso, pois abundam as estratégias de sua aplicação. Uma das mais comuns, em vários países, era utilizar os serviços públicos de saúde para cumprir a disposição de assistência médica e farmacêutica, até o restabelecimento da saúde

19 MENÉNDEZ NAVARRO, Alfredo. "Médicos, medicina y salud laboral en España. Una mirada constructivista al abordaje de las enfermedades profesionales, 1900-1975”. La Mutua, v. 2 Época, n. 18, p. 171-189, 2007, p. 177.

20 DUHAMEL, Georges; RESTREPO, Alonso. “Los excesos del Estadismo y la responsabilidad médica”. Boletín Clínico, v. IV, n. 2 (38), p. 72-96, 1937, p. 80.

21 GOFF, Jacques Le. Du silence à la parole. Droit du travail, société, État (1830-1989). Quimper: Calligrammes, 1989, p. 74. 
do trabalhador. Outra prática comum era atribuir o acidente a doenças sociais: costumes, comportamento indecente, desobediência, imprudência ou descuido. Ambas as práticas cediam ao problema maior da inoperância da lei, por falta de organismos e instituições que a fizessem cumprir.

Com respeito à culpabilidade do trabalhador, com o auge da racionalização científica do trabalho, em torno aos anos 1930, o fator humano da produção começou a ser visto como alvo das ações dirigidas ao aumento do rendimento e da conservação da saúde dos trabalhadores, mediante controle de erros ou predisposições físicas e psíquicas ao acidente. A longo prazo esta preocupação se fez visível nas discussões sobre constituição, seleção, orientação e reeducação funcional do trabalhador. Uma espécie de eugenia laboral quase inexistente na Colômbia, e com força nos países europeus, na Argentina e no Brasil. ${ }^{22}$

Mas essa preocupação com o fator humano corresponde à segunda época da legislação trabalhista, na qual a lógica preventiva já era central. Num primeiro momento, observa-se com nitidez que a prevenção foi secundária, e a política foi fundamentalmente assistencial e compensatória. A explicação possível é que o esquema de seguros de vida produziu um efeito contrário à prevenção, na medida em que desobrigava o patrão da responsabilidade sobre o custo do infortúnio. No sistema de responsabilidade individual que transpassava as companhias de seguros, o peso econômico da indenização, assim como a distância entre patrões e operários, se agudizaram e deslocaram o conflito de classes. Assim como a figura do capataz na indústria atenuava a culpa do patrão, as seguradoras ajudaram na reconfiguração do paternalismo industrial do século XX e na redução dos atritos entre patrões e operários.

\section{Rafael Uribe Uribe, a doutrina do risco e a primeira lei social da Colômbia'3}

Num célebre discurso de 1904 sobre o socialismo de Estado, o político liberal general Rafael Uribe Uribe destacava a necessidade da intervenção estatal para regulamentar o regime do trabalho, além da importância de se legislar sobre acidentes de trabalho. Considerava que, quando por "descuido do empresário, afunda o socavão de uma mina e esmaga ou asfixia os operários", o Estado não podia mirar o sinistro com indiferença. Acreditava também que, em cafezais, trapiches ou engenhos, a lei devesse mandar os patrões ministrarem assistência médica aos peões e melhorar seus alojamentos. Em conclusão, Uribe perguntava se não era uma "anomalia" que os heróis do trabalho e suas famílias fossem abandonados quando "caíam vítimas dos acidentes naturais ou doenças conseguintes". ${ }^{24}$ Posteriormente, na popular conferência Problemas Nacionales, ${ }^{25}$ ele reiterou a necessidade de o Estado legislar para melhorar as condições de vida dos trabalhadores. Esses discursos, assim como o fato (mítico ou real) de levar

22 FERLA, Luis. "O trabalho como objeto médico-legal em São Paulo dos anos 30". Asclepio. Revista de historia de la medicina y de la ciencia, v. LVII, n. 1, p. 237-263, 2005; BUZZI; DEVINCK; ROSENTAL. La santé au travail, 1880-2006; HAIDAR, Victoria, “Todo hombre en su justo lugar": la "solución” biotipológica al conflicto entre productividad y salud (Argentina, 1930-1955)". Salud colectiva, v. 7, n. 3, p. 317-332, 2011.

23 A expressão lei social é a forma como os mesmos autores da época aludem a leis dirigidas à classe operária. Não é exclusiva do país e pode-se observar na literatura sobre o tema na Argentina, Brasil, Chile, Espanha, França, entre outros países.

24 URIBE, Rafael Uribe. Escritos políticos. Medellín: El Ancora Editores, 1984, p. 127.

25 URIBE URIBE, Rafael. Los problemas nacionales. Bogotá: Imprenta Eléctrica, 1910. 
consigo o projeto de lei sobre acidentes de trabalho no dia em que foi assassinado na entrada do Capitólio Nacional, em 1914, forneceram a base sobre a qual se construiu a figura do principal reformador social do país.

A importância política do general Rafael Uribe é inegável. Entretanto, é exagerado colocá-lo como único agente da primeira legislação do trabalho na Colômbia. Na Europa, já se indenizava o dano produzido pelos acidentes de trabalho. Isto era conhecido por ele, mas também por outros políticos colombianos. A necessidade de leis sociais era tema de debate em alguns círculos liberais que consideravam de vital importância para o país a intervenção social do Estado. ${ }^{26}$ Assim, no jornal La Organización, de Alejandro López e Manuel J. Soto, se aludia à campanha de proteção aos operários iniciada por vários liberais da cidade de Medellín, embora "prejuízos, ressábios e injustiças" fizessem com que a ideia avançasse com bastante lentidão. ${ }^{27}$ No mesmo artigo, os redatores destacavam o papel das sociedades estrangeiras e dos indivíduos de outras nacionalidades naturalizados como apoiadores da cruzada de equidade e humanitarismo. Finalmente, concluíam que empresas nacionais como a Ferrocarril de Antioquia e a Empresa Minera El Zancudo tinham cumprido as normas e os estatutos internos cada vez que seus operários foram vítimas de um acidente. ${ }^{28}$

Todavia, mais que uma iniciativa de um reduzido grupo de liberais avançados, a questão foi motivo de discussão igualmente na academia. Em 1911, foram concluídas as teses Indemnizaciones por accidentes de trabajo, do advogado Rafael Abello Salcedo, e Los accidentes de trabajo en sus relaciones con la medicina legal, do médico Benjamim Bernal. A primeira teve na banca examinadora os futuros presidentes José Vicente Concha e Enrique Olaya Herrera, sendo que o advogado Francisco Montaña foi o orientador da tese. A segunda foi examinada por reconhecidos médicos, como Juan David Herrera, Luis Zea Uribe e Miguel Rueda A. O orientador foi o médico Eliseo Montaña, irmão do advogado Francisco Montaña.

Abello propunha uma lei baseada fundamentalmente no projeto da Comissão de Reformas Sociais da Espanha. Bernal apontava uma espécie de deontologia médico-legal em casos de acidentes de trabalho, considerando que, na época, o Congresso estudava um projeto de lei sobre o tema que, se esperava, passaria sem travas por todos os debates parlamentares. O projeto não foi aprovado como imaginava Abello, e foi necessário esperar até 1915, quando Luis de Greiff Obregón, Nemésio Camacho e Manuel J. Soto impulsionaram novamente o projeto de lei sobre acidentes de trabalho.

As opiniões acerca da inspiração desse projeto estão divididas. Há quem afirme que se inspirava no regulamento e na prática médico social das mencionadas empresas de ferrovias e mineração, ${ }^{29}$ o que parece lógico, pela proximidade de Greiff e Soto do círculo liberal de La Organización. Para outros, o projeto tinha sido redigido pelo próprio Uribe e, por isso, era promovido com elogios ao general

26 Sobre o contexto social e econômico no qual se formulou a lei assim como as instituições sociais para os operários veja-se: GALLO. "Trabalho, medicina e legislação na Colômbia, 1910-1914”.

27 LÓPEZ, Alejandro; SOTO, Manuel J. “Accidentes de trabajo”. La Organización, 871. ed. p. 1, 1912.

28 Desde fins do século XIX estas empresas tinham criado serviços médicos, que foram evoluindo para departamentos sanitários, com esquemas mais ou menos completos de assistência médica para os trabalhadores. Entre um paternalismo industrial e a nascente prática de racionalização econômica da saúde, o modelo era precário pois não permitia compromissos de longo prazo como, por exemplo, as pensões por invalidez. Ver: RESTREPO, La práctica médica en el Ferrocarril de Antioquia; GALLO, Óscar, Modelos de assistência médico-social para os trabalhadores na Colômbia, o caso da Empresa Minera el Zancudo, 1865-1948. Ciências Humanas e Sociais em Revista, v. 34, n. 2, p. 122-135, 2012.

29 VILLEGAS GÓMEZ, Hernán Darío. La formación social del proletariado antioqueño, 1880-1930. Medellín: Concejo de Medellín, 1990, p. 194; MAYOR MORA, Alberto. Ética, trabajo y productividad en Antioquia. Bogotá: Tercer Mundo Editores, 1997, p. 142. 
assassinado no ano anterior, ${ }^{30}$ ideia mais próxima da tão problemática figura do precursor, mas sem sustentação empírica.

Em termos doutrinais, a lei sobre acidentes de trabalho se inspirou, na Colômbia como em outros lugares do mundo, nos princípios do risco profissional e do risco de autoridade. ${ }^{31} \mathrm{Na}$ teoria do risco, se partia do pressuposto que o patrão tomava as precauções ao colocar uma máquina em funcionamento, portanto, ele não era culpabilizável da maneira que exigia o direito civil, estando isento de responsabilidade civil pelos acidentes que eventualmente acontecessem. Mas era responsável pela reparação ao trabalhador, pois, em benefício próprio, criava um organismo cujo funcionamento poderia causar (e causa, na realidade) prejuízos. Assim como o empresário era responsável pelos riscos de perdas, deterioração e prejuízos na matéria-prima, maquinaria, edifícios e instrumentos, era também responsável pelos riscos de danos corporais que sofresse o trabalhador por causa dos serviços que prestasse à empresa. Aquele que criou um risco deveria ser responsável por todas as consequências, e, comprovada a causalidade objetiva entre o trabalho da vítima e o prejuízo, era supérfluo provar-se a culpa.

A teoria de risco de autoridade procurava eliminar os obstáculos para que a vítima de um acidente obtivesse uma rápida reparação. Estabelecia a responsabilidade pelas coisas que se tinha sob o cuidado, assim, qualquer acidente que fosse precedido por um contrato de trabalho era responsabilidade do patrão. Caberia a ele provar que não houve culpa ou que não existiu a relação de causalidade. Neste sentido, se invertia o peso da prova, e o trabalhador era dispensado de provar de quem era a culpa do patrão e a causalidade subjetiva e objetiva entre culpa, dano e prejuízo.

Em torno dos anos 1940, como complemento à teoria do risco profissional, surgiu a teoria do risco social, determinando que todos os riscos deveriam ser cobertos por uma instituição especial criada e sustentada com fundos especiais subministrados por empresas, Estado e trabalhadores. ${ }^{32}$ Baseava-se na ideia de que "o trabalhador não trabalha apenas para a empresa, mas também fornece uma positiva contribuição à sociedade com seu esforço, melhorando a economia nacional". ${ }^{33}$ Justamente com o trânsito dos seguros de acidentes, a previdência social se enquadrava nessas duas teorias. No primeiro caso, o único responsável era o patrão, considerado o único beneficiado; no segundo, era a sociedade que compartilhava os benefícios do progresso, portanto, se propunha uma poupança coletiva e solidária.

Nessa perspectiva, a passagem ao modelo da poupança solidária significava a crise do modelo paternalista e assistencial, de corte liberal, baseado em compensações, atenção e indenizações, responsabilidade exclusiva do patrão. Não há como analisar a dimensão dessa mudança, mas a gestão do risco no contexto da previdência social significou o compartilhamento do risco e da culpa. Em outras palavras, o que era uma questão individual se transformou em questão coletiva.

No modelo de risco profissional das primeiras décadas do século XX, a

30 HERNÁNDEZ, Mario. La fragmentación de la salud en Colombia y Argentina: una comparación sociopolítica, 1880-1950. Bogotá: Universidad Nacional de Colombia, Facultad de Medicina, 2004, p. 110.

31 BRADFORD HERRERA, Daniel. "Los accidentes de trabajo en la doctrina y en la ley". (Tesis para optar al grado de doctor en Derecho y Ciencias Políticas, Universidad Nacional de Colombia, Bogotá, 1944).

32 GÁRCES SINISTERRA, Leonardo María. "Resumen de la evolución del concepto de responsabilidad patronal en los accidentes de trabajo". (Tesis de grado para obtener el título de doctor en Ciencias Jurídicas y Económicas, Universidad Javeriana, Bogotá, 1951), p. 50.

33 MORALES BENÍTEZ, Otto. Seguridad social integral. Bogotá: República de Colombia, Ministerio del Trabajo, 1960; MIRANDA, Néstor et al. Historia social de la ciencia en Colombia. Tomo VIII, 2, medicina. La institucionalización de la medicina en Colombia. Santafé de Bogotá: Colciencias. Instituto Colombiano para el Desarrollo de la Ciencia y la Tecnología Francisco José de Caldas, 1993, p. 238-239. 
responsabilidade era do patrão, portanto, o Estado deveria vigiar unicamente o cumprimento das normas, sem qualquer intervenção. $O$ modelo posterior apontava a divisão da responsabilidade, sendo que todos deveriam contribuir para a segurança e o fortalecimento social.

Antes analisar a Lei $n^{\circ} 57$ de 1915, é preciso destacar que ela teve vigência, praticamente sem modificações, até os anos 1950. Apesar dos vários intentos de reforma, entre os quais se destaca o projeto de Código do Trabalho elaborado pelo Escritório Nacional do Trabalho (1928), não houve grandes modificações, até a Lei $n^{\circ} 6$ de 1945. Esta definiu o acidente de trabalho como

toda lesão orgânica ou perturbação funcional que afete o trabalhador de forma transitória, permanente ou definitiva, motivada por um fato imprevisto e repentino, que sobrevenha por causa ou em ocasião do trabalho, sempre que a lesão ou perturbação não seja provocada deliberadamente, por falta grave ou intencional da vítima. ${ }^{34}$

Posteriormente, o Artigo 199 do Código Substantivo do Trabalho (1950), recuperou praticamente toda a definição de 1915: "Todo fato imprevisto e repentino que sobrevenha por causa ou em ocasião do trabalho, e que produza no trabalhador uma lesão orgânica ou perturbação funcional permanente ou temporária, e que não tenha sido provocada deliberadamente ou por culpa grave da vítima." 35

Para se ter uma ideia da permanência da primeira lei social do país, podem ser destacadas as reformas nos seus primeiros trinta anos de vigência. A Lei $n^{\circ} 37$, de 1921, estabeleceu os seguros coletivos obrigatórios para as empresas com capital superior a mil pesos. No ano seguinte, a Lei $n^{\circ} 32$ autorizou a Nação, departamentos e municípios, a funcionar como seguradores de seus próprios trabalhadores; por outro lado, redefiniu o operário como aquele cujo salário não excedesse três pesos ( $\$ 3$ ) diários (lembre-se que o peso equivale aproximadamente a um dólar). A Lei $n^{\circ} 133$ de 1931 determinou, (modificando o Artigo 6 da Lei $n^{\circ} 57$ ), que as incapacidades permanentes parciais deveriam ter indenização de, no mínimo, dois meses de salário e, no máximo um ano; as permanentes totais passaram de um ano a dois anos de indenização. A mesma lei, em seu Artigo 9, aboliu o critério de exclusão por salário e a diferenciação entre empregados e operários. A Lei $n^{\circ}$ 129 de 1931 ratificou os convênios da Organização Internacional do Trabalho entre 1919 e 1931 e, entre outros importantes aspectos, adotou as doenças profissionais incluídas no Convênio da OIT 018 de 1925. O Artigo 4 da Lei n ${ }^{\circ} 165$, de 1941, elevou a prescrição do processo de um para quatro anos.

Em síntese, em termos de leis sobre a saúde dos trabalhadores, as respostas foram tímidas e desarticuladas. Tanto nos governos conservadores de 1910 e 1920, quanto nos governos liberais de 1930 a 1946. Não diretamente relacionada com questões de saúde, sobressaiu-se a Lei $n^{\circ} 83$, de 1931, que legalizou os sindicatos, embora com algumas restrições quanto às greves do setor público. Destacouse também a reforma constitucional de 1936, segundo a qual o trabalho passou a ser uma obrigação social, que desfrutava de especial proteção por parte do Estado. A Lei $n^{\circ} 6$ de 1945 encerrava o ciclo, sendo importante por ter unido várias disposições sobre convenções de trabalho, associações profissionais, conflitos coletivos e jurisdição especial do trabalho.

34 MENESES FRANCO, Efraim. "Enfermedades y accidentes de trabajo". (Tesis de Derecho, Universidad Externado de Colombia, Editorial Prensa Católica, Bogotá, 1949), p. 55-56.

35 REPÚBLICA DE COLOMBIA. Código sustantivo del trabajo y Código procesal del trabajo. Bogotá: Editorial Voluntad, 1964. 


\section{A Lei $n^{\circ} 57$ de 1915 segundo os contemporâneos}

A Lei $n^{\circ} 57$ de 1915 definiu o acidente de trabalho como "um fato imprevisto e repentino, sobrevindo por causa e em ocasião do trabalho, e que produz no organismo de quem o executa, por conta alheia, uma lesão ou perturbação funcional, permanente ou temporária, tudo sem culpa do operário". ${ }^{36}$

De acordo com esta definição, para que o patrão fosse responsável pela reparação dos acidentes que atingissem seus operários, era preciso que, por causa e em ocasião do trabalho, o fato imprevisto e repentino produzisse uma lesão ou perturbação funcional. Ademais, era necessário que o operário não tivesse culpa.

Observadores, como Emilio Robledo, consideravam que, apesar de o legislador colombiano ter utilizado a conjunção aditiva $e$ na expressão "por causa e em ocasião do trabalho", não era necessário que o acidente reunisse dois requisitos distintos. Bastava haver a causa eficiente ou ocasional, estar no lugar de trabalho ou estar trabalhando, não ambas as coisas. Robledo baseava sua opinião nas jurisprudências francesa e espanhola, nas quais o uso da conjunção alternativa ou levava a considerar importante apenas o acidente que tivesse acontecido em ocasião do trabalho. Esta visão, mais de acordo com o espírito social da lei, era compatível, na opinião do advogado colombiano, com o que propunha o legislador.

Entretanto, Júlio César Silva opinava que, precisamente um dos defeitos da lei sobre acidentes do trabalho de 1915, era obrigar a demonstrar que o acidente ocorrera por causa do trabalho e, além disso, sobrevindo na ocasião do trabalho. Para ele, se tratava de uma "prova impossível, absurda e cruel [...], a negação mesma do direito concebido pelo legislador". E concluía: “Tanto valia não ter o direito como não poder demonstrá-lo". ${ }^{37} \mathrm{Em}$ seu parecer, Silva estava certo, por isso, na primeira reforma trabalhista, em 1945 (Lei $n^{\circ}$ 6), substituiu-se e por ou.

Assim, uma intencionada conjunção $e$, por pouco não tornou inócua a lei sobre acidentes de trabalho. O vazio foi remediado, na prática, pelo Departamento Nacional do Trabalho (DNT), que, considerando o duplo requisito contrário ao espírito social da lei, determinou que a ocasião era suficiente, portanto era considerado acidente de trabalho sempre que a vítima realizasse qualquer atividade no local de trabalho. A jurisprudência foi tímida e se manifestou contrária ao reconhecimento dos fatos imprevistos e repentinos sobrevindos no trajeto entre a casa e o trabalho, ${ }^{38}$ tal como se tinha disposto em outros países, como a Argentina.

Que se tratasse de fato "imprevisto e repentino" é ainda mais interessante. A noção de acidente, em linguagem cotidiana, envolvia sempre a ideia de acaso. $\mathrm{Na}$ lógica da lei sobre acidentes, ser necessariamente imprevisível não impediria um conhecimento antecipado, mais ou menos perfeito, das possibilidades. $O$ mineiro preveria que a rocha se precipitaria. O mesmo aconteceria com o policial que recebesse um disparo na perseguição a bandidos, pois isso estaria previsto.

A hermenêutica jurídica acerca da lei sobre acidentes considerava que a ideia de acaso devia ser relativa, nunca absoluta, pois tinha apenas a função de mostrar que o acidente acontecera sem interferência voluntária do operário ou patrão.

36 COLOMBIA. CONGRESO DE LA REPÚBLICA, Ley 57 de 1915 sobre reparaciones por accidente de trabajo, Boletín de la Oficina Nacional del Trabajo, v. II, n. 15-16, p. 749-755, 1931.

37 SILVA, Julio César. "Aspectos del accidente de trabajo y de la enfermedad profesional ante la legislación colombiana”. (Tesis para optar al título de doctor en Derecho y Ciencias Sociales, Universidad Externado de Colombia, Bogotá, 1945), p. 11-12.

38 ABELLO NOGUERA, Osvaldo. “Accidentes del trabajo, vacíos de la legislación y la seguridad social”. (Tesis para optar al título de doctor en Derecho, Universidad Javeriana, Bogotá, 1948), p. 21. 
Obviamente, existiriam acontecimentos anormais e inevitáveis, espécies de "acaso absoluto", sob todos os pontos de vista, que seriam tidos também como acidentes de trabalho. Da somatória desses acidentes fortuitos e desses acasos absolutos surgia o que se chamou risco profissional. ${ }^{39}$

Um exemplo, várias vezes usado na época, argumentava que envelhecer era um fato indefectível, mas que ser pobre era um risco. Por extensão, o risco profissional era o conjunto das eventualidades de um dano, ao qual estavam expostos os que exerciam determinada profissão. Num avião, os passageiros estavam submetidos a riscos, já o piloto, corria um risco profissional, porque seu ofício exigia que ele estivesse permanentemente viajando.

A ideia de fortuito associada à noção de risco profissional também funcionava como divisor de águas entre os acontecimentos imprevisíveis, externos, bruscos, violentos ou de causalidade concentrada, que amiúde tipificavam os acidentes de trabalho; e os acontecimentos considerados riscos normais, mais ou menos previsíveis, temporalmente imprecisos ou de causalidade diluída, como eram as doenças profissionais. Em termos clínicos, não havia grande diferença, porque ao final, eram duas modalidades de estado mórbido. Em termos éticos e sociais, a separação entre acidentes e doenças era desnecessária, pois ambos os estados patológicos deveriam ser indenizados. Em termos práticos, era essencial, porque a legislação colombiana não reconhecia qualquer indenização para as doenças profissionais.

Por outro lado, esse caráter fortuito inerente ao risco profissional importava, porque quando o acidente se produzia por interferência voluntária do patrão, entrava-se no campo do direito penal. O patrão que sabia sobre o risco iminente de a rocha cair ou a máquina explodir e nada fazia, cometia uma dupla infração; portanto, o operário estava no direito de interpor uma ação judicial, sem prejuízo de seus direitos em matéria laboral, pois as leis especiais não excluem a aplicação do direito comum. Em outras palavras, era culpável por descuido ou negligência o patrão que, consciente do estado da maquinaria ou do funcionamento atípico de uma máquina, omitisse qualquer ação que evitasse o acidente; era igualmente culpável todo aquele que, conhecendo um perigo comprovado ou efeito danoso de um trabalho, omitia ou permitia que os trabalhadores continuassem o trabalho, por confiança ou imprudência. Nesse sentido, a falta do patrão podia ser classificada como intencional, inexcusável e culposa, como sugeriam alguns a partir da jurisprudência francesa. ${ }^{40}$

É claro que o mesmo acontecia quando o operário estava consciente ou era negligente diante do perigo. A questão era quem determinava ou separava a consciência da culpabilidade. Para Silva, a bondade ilusória da lei sobre acidentes de trabalho se expressou precisamente nas noções de "culpa" e de "força maior estranha ao trabalho". Com efeito, o patrão era responsável pela reparação ao operário, a menos que o acidente tivesse sido por culpa deste, por força maior estranha ao trabalho, imprudência, descuido, arrojo desnecessário, embriaguez, ataque súbito de doença que o privasse das faculdades mentais ou forças físicas, quebra dos regulamentos da empresa ou violação das ordens expressas dos

39 VILLA, Gabriel Jaime. "La incapacidad permanente en los accidentes de trabajo". (Tesis de Doctorado en Medicina y Cirugía, Universidad Nacional de Colombia, Bogotá, 1942), p. 8.

40 Este filão tem sido aproveitado por vários historiadores para denunciar setores industriais na França e nos Estados Unidos. ROSNER, David; MARKOWITZ, Gerald. "L'histoire au prétoire. Deux historiens dans les procès des maladies professinelles et environnementales". Revue d'Histoire Moderne et Contemporaine, v. 56, p. 227-253, 2009; OMNÈS, Catherine. "De la perception du risque professionnel aux pratiques de prévention: la construction d'un risque acceptable”. Revue d'Histoire Moderne et Contemporaine, v. 56, n. 1, p. 61-82, 2009. 
superiores. Para piorar as coisas, o Artigo 3 reiterava que a culpa era, em geral, "todo ato ou omissão que produza consequências infortunadas". ${ }^{41}$

Assim, os operários eram culpabilizados por não prestarem atenção ao mau estado de um andaime, por exemplo. Já as fraturas podiam ser atribuídas a debilidades ósseas congênitas ou predisposições. Na mesma linha de raciocínio, epilepsia, congestões cerebrais, síncopes cardíacas eram argumentos aproveitados em detrimento dos direitos operários. Ou seja, podiam ser culpabilizados absurdamente pela queda do teto da fábrica depois do golpe do martelo, passando por sofisticados argumentos médicos até provas estatísticas e psicofisiológicas, nas quais se comprovava que unicamente 243 acidentes, de 6.725 foram produzidos por terceiros, ou seja, em 6.482 casos, os patrões puderam provar que a vítima tivera culpa pelo acidente ${ }^{42}$.

Frente à culpabilização permanente do operário, Silva observa com ironia que, se a lei conseguiu ter alguma aplicação saudável, foi por "obra e graça da inspiração de novas ideias que chegavam de tropel até a mente dos juízes e, por acaso, ao coração de alguns empresários".43 Mas, "a sensibilidade social, lamentavelmente, não era erva silvestre na Colômbia". Segundo o mesmo autor, em muitas províncias, "o trabalhador não tinha chegado à categoria de pessoa [...]", ${ }^{44}$ entre outras razões porque "nossos juízes partiam da classe média, a classe dos prejuízos, a incondicional e gratuita defensora do capital alheio, a dos fingidos sentimentos e das posturas cômicas". 45

Através dos artifícios para supressão de responsabilidades usados pelos patrões, é possível perceber uma presença cada vez maior do discurso médicolegal. A função social da retórica médica é paralela à relevância que adquire o discurso médico no âmbito legal. Desse modo, a perícia médico-legal, que antes apenas informava juízes, adquiriu um papel de prova plena; a ciência do direito passou a depender da ajuda do médico para o esclarecimento dos problemas legais. Pois apesar de o juiz sancionar, "o médico é o que indica o sentido da sentença. [...] Ao médico corresponde comprovar a existência da lesão e fixar a diminuição da capacidade operária, aplicando a tabela e seus conhecimentos científicos, ou somente estes". ${ }^{46}$

Esse processo de medicalização do direito não esteve livre de discussões acerca da legitimidade dos campos de saber e das fronteiras e funções das disciplinas. Silva é claro, nesse sentido, quando afirma que aquilo que é verdade para as ciências médicas pode não ser para as jurídicas. Pense-se no caso de uma hérnia: o fator congênito explicaria a aparição da doença, e para o juiz, a força excessiva na execução do trabalho determinaria a aparição do acidente. A ação civil se contentaria com uma "verdade artificial" sobre a qual acordassem as partes. A ação penal, ao contrário, procuraria a "verdade real”, material e essencial. Assim, por uma espécie de hábito profissional, o médico-legista buscaria a verdade na ação civil instaurada pelo operário, quando deveria interessá-lo o critério de justiça social a presidir qualquer hermenêutica das leis protetoras da classe operária.

O terreno em que as divergências entre advogados e médicos se expressaram com maior intensidade foi a classificação das incapacidades e o tipo de indenização

41 COLOMBIA. CONGRESO DE LA REPÚBLICA, Ley 57 de 1915.

42 LLERAS, Roberto. "Consideraciones sobre medicina del trabajo e higiene industrial”. (Tesis para el doctorado en medicina y cirugia, Universidad Nacional de Colombia, Bogotá, 1946).

43 SILVA. "Aspectos del accidentes de trabajo y de la enfermedad profesional", p. 15.

44 SILVA. "Aspectos del accidentes de trabajo y de la enfermedad profesional”, p. 16.

45 SILVA. "Aspectos del accidentes de trabajo y de la enfermedad profesional”, p. 16.

46 SILVA. "Aspectos del accidentes de trabajo y de la enfermedad profesional”, p. 28. 
correlata. O Artigo 5 dividia as consequências do acidente em incapacidade temporária (IT), incapacidade permanente parcial (IPP), incapacidade permanente total (IPT) e morte, ao passo que o Artigo 6 estabelecia as respectivas indenizações para cada um dos tipos de incapacidade. Nos casos de IT, eram pagos, durante o tempo de incapacidade, os serviços de assistência médica e 2/3 do "jornal" 47 ou pagamento diário que o trabalhador ganhava ao tempo do acidente. Na IPP, a assistência cobria o jornal ou pagamento diário inteiro, no mínimo, por 90 dias e, no máximo, 140 dias. No IPT, a assistência alcançava o valor do salário correspondente a um ano, considerando-se o salário semanal que o trabalhador ganhava ao tempo do acidente. Em caso de morte, se pagava o jornal inteiro de um ano aos herdeiros, sendo estes, viúva (indenização completa), viúva e filhos legítimos em partes iguais; se a viúva tivesse se casado novamente, a assistência corresponderia aos filhos unicamente; sem viúva nem filhos, o valor era repassado aos ascendentes, em iguais partes; na ausência destes, ia para seus filhos naturais, e na ausência destes, para os pais naturais ou para aqueles que tivessem a qualidade de tais. Acrescentou-se, ainda, que o patrão poderia empregar quaisquer dos beneficiários no mesmo ofício e com o mesmo jornal "pelo termo de tempo expressado", caso em que o patrão "ficará perdoado da indenização". ${ }^{8}$ Mas se o salário fosse menor, o patrão era obrigado somente a pagar o valor integral aos mencionados herdeiros.

Para minorar a dúvida ou facilitar ao médico-perito a avaliação, em 1935, o DNT resolveu regulamentar as indenizações e classificar as incapacidades criando um padrão de avaliação de onze grupos de acidentes de trabalho. Teve validade até o dia 13 de março de 1946, quando foi introduzida a Tabela de Avaliação de Incapacidade do Trabalho, que teve vigência até 1950, quando foi promulgado o Código do Trabalho.

A principal crítica que se fazia era que a tabela, elaborada pela Academia Nacional de Medicina, não estava baseada em nenhum critério epidemiológico, não tinha correlação com as necessidades da indústria, e as doenças não tinham sido verificadas no âmbito nacional. Em síntese, os acadêmicos haviam privilegiado a dimensão clínica em vez da dimensão laboral, elaborando uma tabela sem consultar especialistas e "copiando códigos antiquados de outros países". 49

Nos comentários acerca da tabela de avaliação aparecem as divergências médicas quanto ao que deveria ser considerado acidente de trabalho ou doença profissional. Também se percebem os interesses de alguns médicos em legitimar o novo campo da medicina do trabalho, em detrimento da Academia Nacional de Medicina e do Instituto Nacional de Medicina Legal. Mais claramente, o que pretendiam os médicos do trabalho era limitar os laudos de acidentes de trabalho e doenças profissionais a médicos especialistas ou médicos da Direção Nacional de Medicina e Higiene Industrial (DNMHI). ${ }^{50}$ Buscava-se defender, assim, uma especialidade para as questões relacionadas com o mundo do trabalho.

Voltando à tabela de avaliação, esta servia para relacionar as diferentes lesões corporais produzidas por ocorrências imprevistas e repentinas, com uma porcentagem de um a cem. Ao menos em teoria, esta gradação devia dar conta

47 Sempre que utilizar a categoria "jornal” faz referencia ao pagamento diário. A expressão jornal é herdeira de uma longa tradição e faz referencia também ao trabalho realizado de sol a sol. Nesse caso traduzido num valor monetário.

48 COLOMBIA. CONGRESO DE LA REPÚBLICA, Ley 57 de 1915.

49 ARANGO BARRENECHE, Gonzalo. "Estudio sobre medicina industrial en Medellín”. (Tesis Doctorado en Medicina y Cirugía, Universidad de Antioquia, Medellín, 1957), p. 112.

50 QUINTERO SANABRIA, Tirso. "Anotaciones a medicina del trabajo". (Tesis Doctorado en Medicina y Cirugía, Universidad Nacional de Colombia, Bogotá, 1949), p. 118. 
da perda de capacidade de execução do trabalho, diminuição da capacidade de lucro ou potencial de consecução de trabalho. Na prática, no entanto, a tabela se mostrou muito limitada, pois concordava mais com a magnitude fisiológica da lesão ou a redução da capacidade muscular do que com a variação na capacidade do trabalho.

Com efeito, avaliar a incapacidade para o trabalho era considerar, acima de tudo, a repercussão do acidente sobre o pecúlio do trabalhador. Qualquer diminuição devia ser calculada em relação a fatores como idade, sexo, profissão, coeficiente profissional, aptidão para ganhar seu salário e para ofício concreto. Por isso, as críticas de advogados e de médicos do trabalho às perícias dos médicos legistas foram muito frequentes.

Os especialistas consideravam que os legistas tinham a tendência a ver a lesão a partir de critérios biológicos. ${ }^{51} \mathrm{~A}$ explicação provavelmente está na confusão entre "incapacidade para trabalhar" e "incapacidade profissional". A primeira era um critério do Código Penal para impor a sanção por feridas, golpes e maus tratos. Avaliava tanto o tempo em que o trabalhador devia curar suas lesões e retomar seu trabalho, quanto a incapacidade, em geral, para qualquer tipo de trabalho físico ou intelectual..$^{52}$ Essa noção era absolutamente diferente do tipo de incapacidade profissional que interessava aos especialistas do trabalho.

Como exemplo das controvérsias alguns médicos se opunham à visão de Guillermo Uribe Cualla, principal médico legista do país, para o qual uma cicatriz facial correspondia a uma invalidez parcial que não limitava o trabalho. Amparados na resolução do DNT, os especialistas em questões de trabalho consideravam que uma cicatriz no rosto, embora não significasse diminuição funcional, de força ou movimento, constituía uma diminuição na capacidade de simpatia ou agrado social. Isso se traduziria em diminuição da capacidade de trabalho, portanto, o operário poderia exigir uma indenização além da que tinha direito pelo acidente. Dessa maneira, se observa claramente que a noção de incapacidade de trabalho abrangia, segundo a autoridade do trabalho:

Um conjunto de fatores psicofísicos que culminam na atividade chamada força de trabalho [...] Considerar a capacidade operária, somente como a força muscular aplicável mediante a direção intelectual, seria uma especulação metafísica [...] A capacidade operária deve interpretar-se como o conjunto de fatores que a integram, sem fazer caso omisso da apresentação fisionômica do sujeito ativo, que, embora não aumente a força muscular nem a direção intelectual que a complementa, mas sim faz a pessoa que a produz, mais ou menos apta para aplicar sua força de trabalho em sociedade. ${ }^{53}$

Na tabela, a incapacidade permanente total correspondia à diminuição de mais de $80 \%$ da capacidade do trabalho. Mas como refletia Silva, como era possível dizer que a perda de $70 \%$ e $50 \%$ não resultava em incapacidades permanentes totais? Ao final, que médico de fábrica recomendaria um operário com a capacidade de

51 O conflito terminou em 1944, quando a Lei $n^{\circ} 77$ de 1948 retirou do dos escritórios de medicina legal os assuntos do trabalho.

52 URIBE CUALLA, Guillermo. Medicina Legal. Bogotá: Editorial Nueva, 1934, p. 152. A dificuldade para saber o que deveria ser incapacidade para trabalhar, na medicina legal, é tão importante, que mereceu várias teses. Ver: RUEDA HERRERA, Hernando. "Estudio médico-legal de las heridas. Su pronóstico y elementos para la evaluación de la incapacidad”. (Tesis para el doctorado en medicina y cirugia, Universidad Nacional de Colombia, Editorial Minerva, Bogotá, 1927).

53 ARANGO SANíN, Agustín. "Medicina Legal y Social. Cicatrices de la cara por accidentes de trabajo". Colombia Médica, v. IV, n. 3, p. 86-88, 1944. 
trabalho diminuída em 50\%? Para o patrão, "esse homem era algo menos que inservível". ${ }^{54}$ Ainda por cima, as indenizações propostas eram ridiculamente irrisórias - à perda perpétua da produtividade, por exemplo, correspondia o valor do salário por dois anos. Nesse sentido, o autor ironizava: "a lei aceita que um homem lesionado pelo trabalho até a invalidez total somente tem direito a dois anos mais de subsistência". ${ }^{55}$

A divergência sobre os critérios em torno dos acidentes de trabalho mostra a impossibilidade médica de capitalizar e objetivar processos dinâmicos como a doença, e mais ainda, de patologias inerentes ao mundo do trabalho, caracterizadas pelo polimorfismo e a multiplicidade de variáveis determinantes. Mesmo esforçando-se por controlar todas as variáveis da atividade pericial, os médicos do trabalho reconheciam que não existia precisão interpretativa sobre a incapacidade. ${ }^{56}$ Numa frase, o delírio classificatório não foi coroado pelo êxito.

$\mathrm{Na}$ historiografia colombiana alusiva ao tema dos acidentes de trabalho, ${ }^{57}$ as críticas à lei têm-se concentrado na definição salarial do operário, incluída no Artigo 1 e nos Artigos 10 e 11, relativos às empresas obrigadas ou dispensadas de pagar indenização. Desses trabalhos, se conclui que a lei não garantia os direitos sociais para a maioria dos trabalhadores, não propunha ações preventivas e fazia predominar um modelo assistencial e compensatório, praticamente sem aplicação. ${ }^{58}$

Quanto ao critério salarial, tinha o defeito de excluir por cima e não por baixo, como insinuam alguns historiadores. Concordava dessa maneira com o espírito social, paternalista ou assistencial que quiseram imprimir os legisladores, ao mesmo tempo em que negava os direitos aos empregados, por considerar desnecessário incorporá-los ao nascente esquema de proteção social. Para se ter uma ideia, em 1929, a média de salário diário industrial do país era de \$1,21 (US\$1,2) peso e de $\$ 36,30$ (US\$36) pesos mensais. ${ }^{59}$ Por isso, quando a Lei $n^{\circ} 32$ de 1922 - que incorporou a Lei $n^{\circ} 57$ de 1915 e a Lei $n^{\circ} 37$ de 1921 , sobre seguros de vida - ajustou o critério econômico a um salário de "três pesos diários" em lugar dos "seis pesos semanais", pretendia ampliar ou, no mínimo, manter a cobertura da classe social que se considerava mais vulnerável. Para os defensores dessa medida, buscava-se evitar que as reparações por acidentes de trabalho atingissem empregados bem remunerados. Finalmente, a Lei $n^{\circ} 133$, de 1931, derrogou o critério de exclusão por salário e a "injustificada diferenciação entre empregados e operários", independentemente da remuneração total que desfrutassem.

Outra forma de limitar os direitos de reparação era considerar responsáveis apenas as empresas cujos capitais superavam mil pesos. Abaixo deste valor, o legislador considerava que se interferia no livre desenvolvimento industrial do país. Assim, o Artigo 10 definiu o tipo de indústrias obrigadas a reparação por acidentes de trabalho: iluminação pública, aquedutos, ferrovias e bondes, licores,

54 SILVA. "Aspectos del accidentes de trabajo y de la enfermedad profesional", p. 34.

55 SILVA. "Aspectos del accidentes de trabajo y de la enfermedad profesional", p. 69.

56 RESTREPO, José Miguel. “Algunos apuntes sobre medicina del trabajo”, Boletín Clínico, v. VIII, n. 4 (88), p. 161-199, 1942, p. 195.

57 Fundamentalmente, ver HERNÁNDEZ. La salud fragmentada; VILLEGAS GÓMEZ. La formación social del proletariado antioqueño, 1880-1930, p. 192-197.

58 ARCHILA, Mauricio. Ni amos, ni siervos: memoria obrera de Bogotá y Medellín, 1910-1945. Bogotá: Centro de Investigación y Educación Popular (CINEP), 1989, p. 121. Coincidindo com outros pesquisadores, ver, por exemplo, ORTÚZAR, Diego. "Legislación y medicina en torno a los accidentes del trabajo en Chile, $1900-$ 1940”. Nuevo Mundo Mundos Nuevos [En ligne], v. Débats, 2013.

59 OFICINA GENERAL DEL TRABAJO, Estadística. Promedios de los salarios industriales y agrícolas en la República según los datos que posee la Oficina General del Trabajo. Boletin de la Oficina General del Trabajo, v. 1, n. 1, p. 40-41, 1929. 
fósforos, arquitetura e construção, mineração e pedreiras, navegação, indústrias com força mecânica e obras públicas nacionais. O Artigo 11 complementa o anterior, determinando que os empresários, industriais ou capitalistas, cujo capital não alcançasse mil pesos ouro (\$1.000) estavam dispensados de pagar indenizações, mas tinham obrigação de prestar assistência médica.

A lógica do legislador entendia que, com menos, dificilmente uma indústria poderia pagar as indenizações por acidentes de trabalho, fato que, na realidade, tinha certa lógica econômica, mas era profundamente chocante, já que, em termos democráticos, estabelecia singularidades e personalismos no acesso aos direitos sociais.

Não há dados acerca de quantas empresas estavam obrigadas a pagar compensações nem quantas eram isentas. Sabe-se que algumas das principais empresas do ramo têxtil tinham, em 1926, um capital superior a \$200.000. ${ }^{60}$ Três anos mais tarde, o Ministério de Indústria informava, após visita dos inspetores do trabalho, que 642 indústrias tinham um capital \$235.245.129,18, uma taxa nominal mensal de $\$ 2.459 .664,75$ e 68.324 trabalhadores $^{61}$. Ou seja, deduz-se das cifras que, ao menos, 642 empresas do país eram responsáveis pelos acidentes dos trabalhadores ou estavam obrigadas a contratar um seguro de vida. Considerando que, desde as Leis $\mathrm{n}^{\circ} 37$ de 1921 e $\mathrm{n}^{\circ} 44$ de 1929, todas as indústrias, agrícolas, de comércio ou de qualquer outra classe, cuja folha de pagamento superasse mil pesos, deviam contratar um seguro de vida equivalente ao salário dos operários ou soldo dos empregados durante um ano.

Em contraste com a quantidade de empresas que, aparentemente, tinham em média mais de $\$ 360.000$, em 1928, o ministro da indústria denunciava que unicamente 150 empresas estavam cumprindo com a obrigação de ter assegurados seus trabalhadores. ${ }^{62}$ Dois anos depois, 89 empresas estavam cumprindo o requisito legal de fornecer seguros de vida para seus trabalhadores, 16 tinham assegurado seus empregados e operários em companhias de seguros, ao passo que, entre 1923 e 1930, 73 empresas criaram suas próprias seguradoras.

Cabe frisar que não se deve confundir a indenização por acidente e seguro de acidentes de caráter discricional com o seguro coletivo de vida obrigatório, que é uma previdência social; porém, as bases de cálculo de capital e salários são guias para ambos os casos. Finalmente, é preciso lembrar que, ao fim dos anos 1940, o sistema mudou, e a responsabilidade econômica sobre os acidentes ou a saúde dos trabalhadores passou a ser dividida entre o patrão, o trabalhador e o Estado, dando forma ao sistema de previdência social.

O terceiro critério de limitação ou exclusão da lei sobre acidentes de trabalho se dava, como já apontado, pelo tipo de indústria, sendo notoriamente deficiente e arbitrário (se limitando a iluminação pública, aquedutos, ferrovias e bondes, licores, fósforos, arquitetura e construção, mineração e pedreiras, navegação, indústrias com força mecânica e obras públicas nacionais). Para vários autores, o legislador de 1915 considerou necessário incorporar exclusivamente as empresas cujos meios mecânicos de produção eram vistos como perigosos para a saúde dos

60 Rosellón, 200 teares, capital \$216.000; Fábricato, 150 teares, capital \$160.000; Coltejer, 140 teares, capital \$94.000; Caldas, 180 teares, capital \$200.000. MONTENEGRO, Santiago. El arduo tránsito hacia la modernidad: historia de la industria textil colombiana durante la primera mitad del siglo XX. Bogotá: Editorial Universidad de Antioquia, 2002, p. 141.

61 OFICINA GENERAL DEL TRABAJO. Cuadro que manifiesta el estado de las industrias del país visitadas por los inspectores del trabajo en el año de 1929. Boletín de la Oficina General del Trabajo. v. 1, n. 4, p. 279280, 1930; REPÚBLICA DE COLOMBIA. MINISTERIO DE INDUSTRIAS. Memoria del Ministerio de Industrias al Congreso Nacional en sus sesiones ordinarias de 1929. Bogotá: Tipografía romana, 1929, p. 170.

62 HERNÁNDEZ. La salud fragmentada, p. 81. 
trabalhadores. Dessa maneira, os trabalhadores dos setores agrícola e pecuário foram excluídos até 1938, quando o DNT determinou que os trabalhadores das empresas agrícolas com produção mecânica tinham direito igualmente a reparação por acidentes de trabalho.

Limitado ao setor industrial, o sistema legal de acidentes de trabalho favoreceu uma porcentagem mínima da população economicamente ativa e manteve os agricultores desprotegidos, justamente o setor mais importante da economia nacional. De acordo com os cálculos da CEPAL, em 1925, a Colômbia contava com uma população de 6.724 .000 habitantes, dos quais 2.505 .000 eram economicamente ativos. Desses, $68,6 \%$ trabalhavam no setor agrícola, $1,6 \%$ na mineração, 3,4\% na indústria fabril, 7,9\% na artesanal, 1,8\% na construção e 16,7\% em comércio, finanças, empregos públicos, transporte, comunicação e energia. ${ }^{63}$

Para os operários industriais, a situação era mais difícil, pela ação simultânea das três regras de exclusão: o operário teria que trabalhar para alguma empresa dos setores enumerados; a empresa deveria superar o capital de mil pesos; o salário não deveria superar seis pesos. Todavia, no grupo de operários "privilegiados" existia o subgrupo dos igualmente desprotegidos pela negligência tranquila ou a resistência dilatória e sistemática dos patrões. As empresas visitadas pela inspeção do trabalho tinham 68.324 operários, o que representava cerca de $2 \%$ da população economicamente ativa do país e, aproximadamente, $8 \%$ da população economicamente ativa do setor industrial em sentido amplo. Acrescente-se a isso o baixo nível de compromisso com os seguros de vida, não ficando difícil imaginar a precariedade laboral de praticamente toda a classe operária.

Os Artigos 8 e 9 determinavam as questões relativas à atenção médica. Assim, a obrigação mais imediata de todos os patrões era proporcionar ao operário lesionado os serviços médicos, cirúrgicos, farmacêuticos, de laboratório, hospitalar e alimentícios. O patrão, sem exceção ou demora, devia conduzir ao auxílio médico mais próximo e, depois, ao médico escolhido. A empresa era livre para contratar quem desejasse para a assistência médica, sempre que se tratasse de médicos graduados. Tinha, igualmente, plena liberdade de contratar para seus operários um seguro de qualquer sociedade devidamente constituída.

Com mais astúcia que resistência, para a assistência médica contemplada na norma, inclusive nos casos em que o operário tivesse culpa pelo acidente, como determinava o DNT, os patrões aproveitavam os hospitais de caridade para socorro e perícias. Fraturas, luxações, queimaduras, extração de corpos estranhos ocuparam o cotidiano dos médicos oficiais de diferentes regiões do país. Em alguns casos, se podia estabelecer um pacto econômico entre empresa e autoridades municipais, de maneira que os operários tivessem certos privilégios. Mas nem sempre tal acordo favorecia as frágeis instituições hospitalares da maioria das cidades da Colômbia. Por outro lado, este ato de autonomia patronal mantinha os serviços médicos nos limites do paternalismo. Os médicos, embora com duvidosas intenções, se manifestaram em favor do direito de escolha do trabalhador quanto à assistência médica e hospitalização.

Nesse horizonte da assistência médica houve um acerto. Por descuido, o legislador não colocou qualquer limite no que dizia respeito aos gastos que demandava esta prestação social. Nos outros aspectos, a imprevisão do legislador se explica unicamente pela confluência de interesses econômicos da classe política

63 VEGA CANTOR, Renán. Gente muy rebelde: enclaves, transportes y protestas obreras. Bogotá: Ediciones Pensamiento Crítico, 2002, p. 352. 
e da burguesia industrial. David Bradford parece corroborar esta suspeita quando afirma que, se em termos doutrinais, os excluídos dos benefícios eram poucos, à luz da lei positiva, "o número de vítimas do trabalho privados do direito à reparação aumenta consideravelmente". 64

Para completar o panorama de falências, os Artigos 12 a 16, relacionados fundamentalmente com questões procedimentais são contundentes. Segundo o Artigo 12, os patrões deveriam avisar o juiz municipal, por escrito, sobre hora, lugar, causas, testemunhas, nome da vítima, local para onde foi trasladado o trabalhador lesionado, os médicos que o assistiram, salário e razão social da companhia de seguros. Tudo isso em, no máximo, 24 horas depois do acidente. Em caso de morte, previsto no Artigo 13, o patrão deveria comunicar o juiz competente.

Os Artigos 14 e 15 especificam os aspectos relativos ao procedimento, declarando que os documentos, assim como as declarações dos envolvidos, tinham caráter de informação judicial, caso houvesse controvérsia sobre o acidente. Os processos eram levados à justiça comum, nos tribunais municipais. O Artigo 16 considerava nula a renúncia aos direitos que os preceitos legais sobre acidentes de trabalho concediam aos trabalhadores. Tal nulidade não ia contra transações, compromissos ou arbitramentos celebrados depois do acidente. Todo o processo tinha tempo de prescrição de um ano, de acordo ao Artigo 17.

Independentemente da demanda judicial e da reparação sem sentença condenatória, o patrão tinha a obrigação de comunicar o acidente ao respectivo tribunal municipal. Assim, a Empresa Minera El Zancudo reportou o acidente de Juan B. Restrepo:

Zancudo, Março 16 de 1926

Senhor Juiz Municipal do distrito de Titiribí Presente.

Em cumprimento do Artigo 12 da Lei $n^{\circ} 57$ de 1915 me permito avisar-lhe que o senhor Juan B. Restrepo, operário da Empresa de Zancudo, sofreu, no setor Hulleras, um acidente de trabalho consistente na trituração do mindinho da mão direita e outras lesões de menor significação na mesma mão.

Foi trasladado ao Hospital de Titiribí, onde o médico da empresa, Dr. Jaime Orozco, lhe amputou as duas primeiras falanges do mencionado dedo. Atualmente, se encontra no dito hospital, ao cuidado do mesmo Dr. Orozco. Ganhava um jornal de seis pesos $(\$ 6,00)$ semanais. Gozará, enquanto dure a incapacidade, das duas terceiras partes do salário, de acordo com a lei citada antes. ${ }^{65}$

Muitas outras declarações devem ter sido registradas no tribunal municipal daquele importante distrito mineiro. O objetivo era prevenir "emboscadas e defesas habilidosas, quando tivessem desaparecido as de prova que sustentavam ou coadjuvavam a ação do trabalhador". ${ }^{66}$ De fato, nos casos em que patrão ou operário não concordaram sobre os procedimentos, as causas, o momento em que o acidente ocorreu, sua classificação, entre outros aspectos, ao menos existia esta espécie de "confissão extrajudicial".

Provavelmente, o legislador considerou oportuno, dada a capilaridade da justiça comum, que os conflitos entre operários e patrões se resolvessem

64 BRADFORD HERRERA. "Los accidentes de trabajo en la doctrina y en la ley", p. 76.

65 ARCHIVO MUNICIPAL DE TITIRIBÍ. Fondo Alcaldía Varios. Carta marzo 16 de 1926.

66 BRADFORD HERRERA. "Los accidentes de trabajo en la doctrina y en la ley”, p. 106. 
mediante demandas civis ante o juiz mais próximo ao local do acidente. Mas era, sob todos os aspectos, uma disposição problemática, pois desconsiderava a lógica conflitiva das relações de classe entre operários e a burguesia industrial, além de ser incongruente com relação à política do país e à legitimidade do Estado colombiano, armada em torno de um centro abissalmente ausente. Não só faltavam mecanismos de verificação e sanção para o cumprimento das leis, mas havia a demora nos processos, que eram dispendiosos.

Destarte, terminava por complicar-se o que estava resolvido em termos doutrinais, ou seja, a responsabilidade do patrão em qualquer caso de acidente de trabalho. Com o agravante de que, no processo, à sempre duvidosa inocência do operário restava importância à presunção de responsabilidade do patrão. Três instâncias e três documentos deveriam comprovar o acidente e as palavras do operário: certificado do chefe de trabalhos ou chefe de equipe; certificado do médico da empresa ou do médico-legal; três testemunhos de operários.

Finalmente, nas reclamações em que havia controvérsias sobre a lei e as indenizações, a documentação era enviada aos respectivos escritórios de medicina legal ou ao DNT. Esta entidade, por sua vez, nomeava um perito da Academia Nacional de Medicina ou outra corporação científica. Desde 1946, a Direção de Medicina e Higiene Industriais do Ministério do Trabalho era a entidade responsável de qualificar o acidente, fixando a incapacidade definitiva de acordo com a tabela de avaliação do Ministério do Trabalho.

Entre o começo e o fim de um processo se estimavam, em média, dois anos. Entende-se por que poucos trabalhadores levaram ao nível jurídico a reivindicação dos seus direitos. Não se pode esquecer que tinha vantagem aquele com "menos urgência na solução do litígio e maior capacidade econômica para alimentar indefinidamente a controvérsia, com recursos e provas" ${ }^{67}$ Isso sem contar a proximidade do patrão e das autoridades políticas, de juízes e árbitros.

Para remediar a situação, enquanto se criava a jurisdição especial do trabalho, o legislador determinou que, a partir de 1934, o trâmite seria realizado mediante o procedimento verbal. A Lei $n^{\circ} 45$ de 1939 estendeu este procedimento a qualquer aplicação das leis sociais. As audiências se multiplicaram e fragmentaram os processos; entre a prolongada tramitação verbal, a notificação da sentença, as apelações e a liquidação da sentença, a média de dois anos se manteve. O mais absurdo de tudo era que o Artigo 17 da lei dispunha que as ações estabelecidas em favor do trabalhador prescreveriam ao término de um ano.

\section{Reflexões finais sobre acidentes de trabalho}

Ao longo deste artigo, foi possível observar os vazios ou critérios de exclusão da primeira lei social do país, a de $\mathrm{n}^{\circ} 57$ de 1915. Em resumo, os trabalhadores que não tinham direitos eram os que sofriam de lesão ou doença não imprevista e repentina, ou seja, uma "doença profissional", causada pelo trabalho; aqueles que, apesar de executar um trabalho por conta alheia, careciam de contrato de serviços; até os anos 1930, os empregados e patrões com salários superiores a três pesos; os operários comprovadamente culpados pelo acidente; os que sofressem acidentes de força maior, estranha ao trabalho; os operários que prestavam serviços em empresas com capitais menores a mil pesos; os assalariados de empresas não contempladas no Artigo 10, ou seja, todas as que não fossem de

67 BRADFORD HERRERA. "Los accidentes de trabajo en la doctrina y en la ley”, p. 107. 
iluminação pública, aquedutos, ferrovias e bondes, licores, fósforos, arquitetura e construção, mineração e pedreiras, navegação, indústrias com força mecânica e de obras públicas nacionais.

A solução, como observam vários autores, era pagar a reparação por acidente de trabalho em todos os casos, mesmo que se pudesse provar a culpa do operário. Os opositores desta ideia sugeriam que assim se premiava o descuido e a falta de atenção do trabalhador. Os defensores da ideia, por sua parte, afirmavam que rejeitar a proteção ao trabalhador inválido e à família negava o fim social buscado pela lei. Estavam de acordo sobre o fato que, a longo prazo, era mais rentável pagar por todos os riscos, já que isto teria como consequência reduzir a "desmoralização" do operário, causa habitual do "acidente de trabalho intencional", o "autolesionismo" ou a "simulação". Além disso, havia que se considerar que, muitas vezes, a culpa era consequência da fadiga, das rotinas industriais produzidas pelo maquinismo e da inevitável familiarização com o perigo da máquina, que atenuava a precaução. A reparação pecuniária e a reeducação funcional dos incapacitados industriais era o mínimo que se deveria fazer, como observaram alguns médicos; assim, a principal função da intervenção social neste campo deveria ser a prevenção da acidentalidade. ${ }^{68}$

Recebido em 09/02/2015 Aprovado em 23/08/2015

68 ARISTIZABAL OSPINA, Fabio. "Legislación de los accidentes de trabajo". (Tesis de grado para obtener el título de Doctor en Ciencias Jurídicas, Universidad Javeriana, Editorial Aguila, Bogotá, 1939), p. 49. 
